\title{
The lynx cycle: a climatic perspective
}

\author{
P. A. Scott, Ian T. M. Craine \\ Department of Zoology, University of Toronto, Toronto, Ontario, Canada M5S 1A1
}

\begin{abstract}
A tree growth index from central Canada that covers the period 1710-1982 was calibrated to local Churchill (Manitoba, Canada) summer temperatures for 1932-90. The temperature and precipitation series of the calibration period and other proxy data were used to determine the changes in atmospheric circulation which were compared to the 1735-1934 lynx cycle as derived from Hudson's Bay Company fur returns. The 3 phases of the lynx cycle coincide with 3 phases in the general circulation. The first phase occurs during a warm period (1735-1820), has small fluctuations, and the periodicity is variable. The second phase occurs in the last resurgence of the Little Ice Age (1821-1913) and has a classical $10 \mathrm{yr}$ cycle. The third phase occurs during the warming at the end of the Little Ice Age, has declining frequencies, and appears to have a decaying periodicity. Other studies have shown a trend towards cycling in predator populations across a latitudinal climatic gradient. This is the first study to our knowledge that demonstrates a switch to cycling in predator populations at 1 location in response to climatic change over time. We postulate that during a cool period a reduction in prey would encourage predators to become specialized which could thereby initiate cycling. During a favourable period the predators may become more generalized in response to increased prey availability resulting in non-cyclic populations
\end{abstract}

\section{INTRODUCTION}

Adaptation of mammal populations to a changing environment is ongoing and necessarily lags in response. Arguably, one response to environmental conditions is the well documented periodic fluctuations in numbers, or population cycling (Krebs \& Meyers 1974, Pimm 1991). However, the relationship between cycling behaviour and the changing environment has not been fully determined. Severe weather events such as freezing rain may have a detrimental effect on overwintering mammal populations (Pruitt 1978, Courtin et al. 1991, Marchand 1991) which may reduce populations and dampen cycles. An extreme event in marginal environments can result in the extirpation of a local population such as documented in musk-oxen (Barr 1991) although studies on lemmings, for example, indicate that the effect may be indirect (Shelford 1943, Scott 1993). Certainly, the fluctuations in number of mammals are often periodic and, therefore, are not the product of irregular weather processes. However, to understand both the origins of population cycles in mammals and the environmental sensitivity of a population, it is essential to examine long-term patterns within a climate perspective - that is, how the animal under study is currently adapted to the prevailing environment.
Cycling in mammal populations apparently increases in amplitude as species diversity declines (Keith 1963, Wolfe 1980, Pimm 1991, Henttonen et al. 1992). A spatial example is demonstrated by Hansson \& Henttonen (1985) where the cycling amplitude increases with increasing latitude in Finland and Sweden, coinciding with a more severe climate and reduced species diversity. The few long-term studies available indicate that population cycling in mammals is intermittent (Elton \& Nicholson 1942, Steen et al. 1990, Scott 1993). The Canada Lynx cycle as originally synthesized by Elton \& Nicholson (1942) for example, has 3 distinct phases of amplitude (Schaffer 1984): (1) the early phase $(1735-1820)$ when fluctuations are few and the dynamics were unique; (2) the middle phase (1821-1913) that defines the classic $10 \mathrm{yr}$ cycle which shows higher amplitudes; and (3) the later phase (1914-1934) that is characterized by reduced fluctuations and a decaying periodicity. Dominion lynx trapping statistics for the period 1919-1973 (Fox 1978 ) illustrate the later decline phase described by Schaffer (1984), which continues into the 1950s. Further, a fourth phase, characterized by increasing amplitude, is evident during the late 1950s, 1960s and early 1970 s. 
The trapping for lynx was initially done around the west coast of Hudson Bay and later inland throughout central Canada. Recent studies of tree growth (Scott et al. 1988) at Churchill, Manitoba, $\left(58^{\circ} 45^{\prime} \mathrm{N}, 94^{\circ} 05^{\prime} \mathrm{W}\right)$ on Hudson Bay reveal the same 3 phases in growth. These phases apparently coincide with changes in large-scale atmospheric circulation patterns in the centre of the North American continent (see Bryson 1966, Barry 1967, Guiot 1985).

To examine the influence of a changing climate on population cycling, we developed a long-term climate perspective and compared it with populations of lynx as determined from the records of lynx fur traded from 1735 to 1934 (Elton \& Nicholson 1942). Modern weather data were used to calibrate the 1710-1982 tree growth index (Scott et al. 1988) with summer temperature and then to classify different climate regimes. The modern climate analogues were uscd to cstablish the previous temperature regimes and determine changes in atmospheric circulation which were then compared to the 3 phases of the lynx cycle.

\section{METHODS}

The monthly temperature and precipitation summaries for Churchill were obtained from Environment Canada (Churchill Weather Office, Churchill, Manitoba). The average temperature and coinciding rainfall anomaly for each summer growth period (July and August; Scott et al. 1987) from 1932 to 1990 were classed in $0.25^{\circ} \mathrm{C}$ increments and examined for distinct patterns - patterns that may be analogous to earlier conditions.

The tree growth index was developed from the work of Scott et al. (1988). In summary, after coring and examining some 3500 white spruce along a $50 \mathrm{~km}$ segment of the treeline near Churchill, Manitoba, 11 representative specimens were sampled. The site history for each tree was investigated, the height increments and branch locations were measured, and the trees were felled. Disks of wood were cut at the mid-point of each node, or at $10 \mathrm{~cm}$ intervals when the nodes were not obvious, and sanded. The ring widths were measured on the 4 cardinal directions using a tree ring increment measuring system (Fayle et al. 1983). Specific Volume Increment (SVI) was determined by calculating the volume of the growth layer for each year and dividing by the surface area of the cambium that produced it. The SVI is a ratio reflecting the volume realized for any given year relative to the potential for production that was established in the previous year. A tree growth index based on SVI was calculated using a multivariate autoregressive moving average [ARMA $(1,4)$ ] model (Monserud 1986). The
ARMA $(1,4)$ model accounts for the effects of events in 1 year on growth during the subsequent year as well as the contribution of an annual needle crop to growth over the next 4 yr. Each series was then standardized by using a negative exponential curve or line of negative slope if necessary and dividing the residuals by the series standard deviation (Fritts 1976).

The tree growth index was calibrated by comparing a 5 yr running average in SVI with corresponding summer temperatures during the 1932-1990 period. The curve was logarithmic below $10.5^{\circ} \mathrm{C}$ and above $12.5^{\circ} \mathrm{C}$, and approximately linear within this range. A linear regression (Sokal \& Rohlf 1981) was used with the 40 central values to determine the index value at $0.5^{\circ} \mathrm{C}$ increments between $10.5^{\circ} \mathrm{C}$ and $12.5^{\circ} \mathrm{C}$. This heat index is compared to the lynx cycle as synthesized in Elton \& Nicholson (1942).

\section{RESULTS}

During the 1932-1990 year record period, average summer temperatures at Churchill have varied from less than $10^{\circ} \mathrm{C}$ to greater than $14^{\circ} \mathrm{C}$ (Fig. 1). Each type of summer appeared discrete and multi-year periods dominated by one type of summer were rare. Warm summers characterized by average temperatures above $13.25^{\circ} \mathrm{C}$ occurred approximately $20 \%$ of the time. Eight of 11 warm years were dry, typical northern prairie summers, with little rainfall and moisture deficits caused by the resulting increase in evapotranspiration. Moderate summers ranging from 13 to $11.5^{\circ} \mathrm{C}$ occurred approximately $40 \%$ of the time. The moisture regime was highly variable. Cool summers also occurred around $40 \%$ of the time and were characterized by temperatures around $11^{\circ} \mathrm{C}$ and colder. During cool summers the rainfall was slightly greater and the evaporation was less making conditions much wetter. The high frequency of low quantity rainfall events during the cool summers indicates persistent low pressure systems characteristic of tundra or low arctic climates (Barry et al. 1981).

Temperature changes can be inferred from the tree growth index (Fig. 2). Cold Little Ice Age conditions dominated in the northern hemisphere throughout the 1600 s (Lamb 1982). A slight warming trend beginning around 1720 , peaking around 1780 , and cooling again by 1836 is evident. The Little Ice Age climate continues until a warming trend becomes noticeable during the 1880 s and rises abruptly during the 1920s. After the 1930 s and 1940s, the warmest period in the $275 \mathrm{yr}$ chronology, the remainder of the 1932-82 calibration period is characterized by ongoing cooling.

The calibration of the chronology reveals that the normal mean summer temperature at Churchill during 
Fig. 1. Average summer temperature (July and August) and precipitation anomalies at Churchill, Manitoba, Canada, 1932-1990. There is evidently a gap between warm summers and moderate summers at around $13^{\circ} \mathrm{C}$ and also between moderate summers and cool summers at around $11.5^{\circ} \mathrm{C}$. These gaps apparently represent switches in air mass frequency that results in different weather conditions

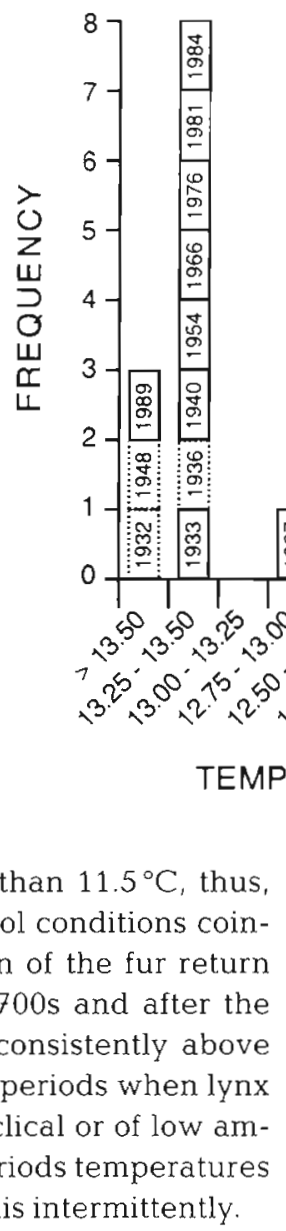

RAINFALL ANOMALY

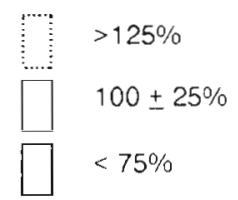

the Little Ice Age was usually less than $11.5^{\circ} \mathrm{C}$, thus, Arctic summers prevailed. These cool conditions coincide with the classical cyclic pattern of the fur return data. During the warming in the 1700 s and after the Little Ice Age, temperatures were consistently above $11.5^{\circ} \mathrm{C}$ and coincide closely to the 2 periods when lynx fur returns were apparently non-cyclical or of low amplitude cycles. Within the 2 warm periods temperatures ranged to $13^{\circ} \mathrm{C}$ but only exceeded this intermittently.

\section{DISCUSSION}

The changes in phase of the lynx data do not seem to be the result of changes in human activity. While there has been ongoing technological development in central Canada over the past $300 \mathrm{yr}$, the trends created by such changes are not reflected in the overall lynx cycle from 1735 to 1973 . For example, the infrastructure for accessing and marketing fur-bearing

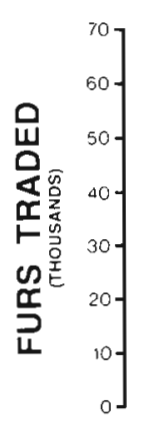
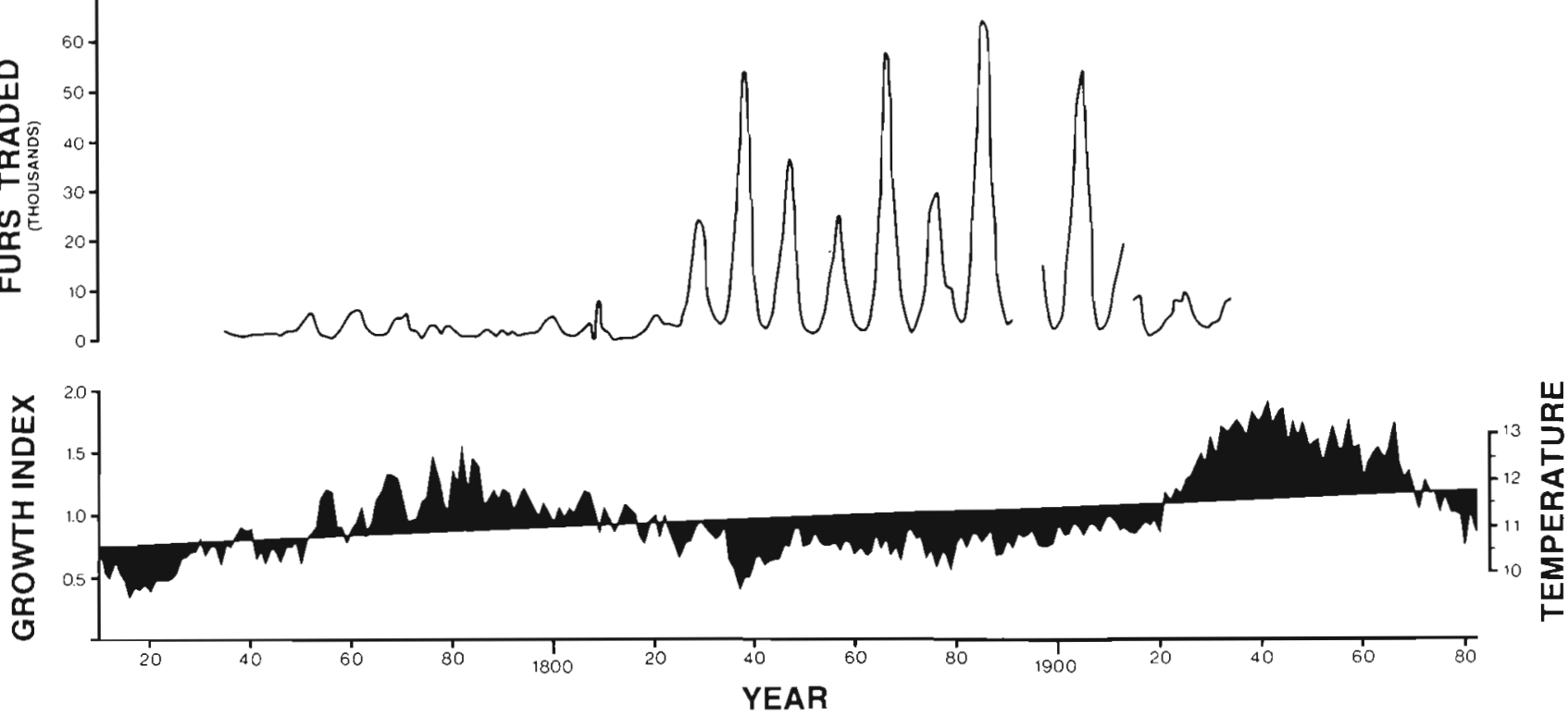

Fig. 2. The lynx fur returns reported in Elton \& Nicholson (1942) for 1735-1934 compared with the calibrated tree growth index for the region around Churchill, Manitoba, Canada (Scott et al. 1988). The shifts into and out of the 10 yr cycles correspond to shifts in summer temperature to below and then above $11.5^{\circ} \mathrm{C}$ 
animals has improved, yet there has been no corresponding increase in total numbers of furs returned. During the climate warming in central Canada in the 1920s, 1930s, and 1940s, declining numbers of lynx furs were returned (Fox 1978). Yet, during the subsequent cooling period in the late 1950s, 1960s and 1970s, near extinct lynx populations (Keith 1963) remarkably recovered and fur returns increased dramatically (Fox 1978). This does not correspond directly with the human population explosion and technological boom that characterizes the 20th century. Further, increased trapping pressure associated with the human population expansion does not coincide with the high amplitude phase of the lynx cycle. For example, under the carefully regulated harvesting methods in effect during the 1960s and 1970s, the high amplitude periodicity resumed in many regions (Fox 1978).

Unpredictable events, such as the smallpox outbreak in Canada from 1777 to 1790 , or social upheavals, do not correspond with the phase changes in the lynx cycle. The traders maintained consistent practices during these transitional periods (Elton \& Nicholson 1942). The trapping of lynx is often an incidence of fox trapping (Quinn \& Thompson 1987) and therefore a decline in furs from the lack of trapping would also be reflected in fox fur returns. In fact, fox species fluctuate with a 4 yr periodicity (Pimm 1991). The 2 phases of the lynx cycle where the periodic fluctuations are reduced or absent also have substantially reduced average number of furs. This cannot be explained simply by changes in trapping effort. London fur auction prices varied with consumer demand independent of trapping activities. Hudson's Bay Company clerks were grateful to accept any furs brought to the posts (Newman 1985, Barr 1991). If the trappers had run into temporary difficulties in supplying the furs to the trading posts it would be expected that the average number of furs traded would increase in subsequent years and there would be little change in the overall average.

The dominance of different air masses in the centre of North America creates distinctive climate patterns that may persist throughout a season (Bryson 1966). Recent examination has documented the annual switching between dominant patterns of summer at Lynn Lake, a boreal forest location near the ManitobaSaskatchewan border (Scott 1992). The separation between the 2 dominant summer temperature regimes at Churchill occurs just above $11.5^{\circ} \mathrm{C}$, which also coincides with the shift between phases of the lynx fluctuations. The change associated with beginning of the warm period during the 1700 s has been indicated by analysis of Hudson's Bay Company records (Ball 1985) and other proxy climate data (Guiot 1985). One noted change was a shift in the prevailing winds from north (arctic) to west (boreal) during the warming. Sub- sequently, before the resumption of the Little Ice Age around 1820, a highly unstable (i.e. variable) period in central Canada created considerable stress on plant, animal, and human populations (see Ball 1992a, b. Fayle et al. 1992, Jacoby \& D'Arrigo 1992, Suffling \& Fritz 1992, and references therein). For example, at the Osnaburg trading post in central Ontario, moose meat was an important food source for Hudson's Bay Company employees. Yet it was not traded and apparently unavailable from 1820 to 1890 (Suffling \& Fritz 1992). The 1820 period is also when the lynx cycle shifted phases. This demonstrates that changes in the Iynx cycle are either a direct or indirect response to changes in the general atmospheric circulation in central Canada.

The cyclic behaviour of the lynx fur returns coincides with the cold period. In some areas the cold period is associated with less snow (Lavoic \& Payctte 1992) although during the recent cooling trend the snowfall has apparently increased in the north (Barry 1990). Powdery snow renders depositional areas largely inaccessible to predators whereas crusty snow is most often favorable habitat (Halpin \& Bissonette 1988). Contrary to popular misconceptions (e.g. Arditi 1979) snow crusts soften up and become impassable for lynx at approximately $-25^{\circ} \mathrm{C}$ (Scott pers, obs.). Therefore, low mid-winter temperatures in deep snow environments will be essential for successful lynx predation on hares and detrimental to hare survival (Meslow \& Keith 1971). The hard crust snow conditions result from re-distribution of snow and are largely independent of variations in snowfall (Scott et al. 1993). The consistency of lynx populations (Elton \& Nicholson 1942, Quinn \& Thompson 1987), and the persistence of cycling in small mammal prey species (Fuller 1977), over a range of snow conditions indicates that the depth of snow is less important than the timing of the snowfall (Henttonen et al. 1992). For example, arctic and subarctic regions characteristically have very little snowfall until the end of winter in March or April (e.g. Scott et al. 1993). In more temperate regions the snowfall regime may be more uniform. A shift between these types of snow regimes could influence lynx populations or their prey species.

The main relationship between lynx abundance and climate regimes is likely an indirect influence. Greater summer heat availability will increase the biomass production in photosynthetic organisms resulting in slight increases in the density of first order consumers (e.g. Krebs 1988) and perhaps in the number of species. With greater prey availability predators may generalize (Hansson \& Henttonen 1985). Consequently, predator populations become more stable and prey populations fluctuate in complex complementary cycles (Greenwood 1987, Korpimaki \& Norrdahl 1989). This may 
explain the dampening of the lynx cycles during the warm periods of the last $200 \mathrm{yr}$. During re-establishment of the Little Ice Age, specialization among predators, specifically of lynx predating on hare, would lead to the return of cyclic lynx populations

The switch from cyclic to non-cyclic behaviour in lynx occurs in response to a change in the mean summer temperature of as little as $1^{\circ} \mathrm{C}$. Future global warming may increase mean summer temperatures in northern latitudes by at least that amount, and this would no doubt destabilize predator-prey relationships. The results reported here demonstrate the sensitivity of natural systems to changes in climate and highlight the significance of non-linear responses in our understanding of ecosystem dynamics.

Acknowledgements. We thank R. G. Barry for helpful discussions and D. Fayle, H. Henttonen, K. Martin, S. Pimm, $K$. Stuart-Smith and an anonymous reviewer for helpful comments on the manuscript. Thanks also to R. Hansell and the Environment Canada staff at the weather office for their cooperation and support. This study was supported by N.S.E.R.C., the Northern Scientific Training Program.

\section{LITERATURE CITED}

Arditi, R. (1979). Relation of the Canadian lynx cycle to a combination of weather variables: a stepwise multiple regression analysis. Oecologia 41: 219-233

Ball, $T$. (1985). A dramatic change in the general circulation on the west coast of Hudson Bay in 1760 A.D.: synoptic evidence based on weather records. In: Harington, C. R. (ed.) Climatic change in Canada - 5. Syllogeus 37: 219-228

Ball, T F. (1992a). Climatic change, droughts and their social impact: central Canada, 1811-20, a classical example. In: Harington, C. R. (ed.) The year without a summer? World climate in 1816. Canadian Museum of Nature, Ottawa, p. 185-195

Ball, T F. (1992b). The year without a summer its impact on the fur trade and history of western Canada. In: Harington, C. R. (ed.) The year without a summer? World climate in 1816. Canadian Museum of Nature, Ottawa, p. $196-202$

Barr, W. (1991). Back from the brink. Komitik Series, No. 3. The Arctic Institute of North America, Calgary

Barry, R. G. (1967). Seasonal location of the arctic front over North America. Geogr. Bull. 9: 79-95

Barry, R. G. (1990). Evidence of recent changes in global snow and ice cover. Geojournal 20: 121-127

Barry, R. G., Courtin, G. M., Labine, C. (1981). Tundra climates. In: Bliss, L. C., Cragg, J. B., Heal, D. W., Moore, J J. (eds.) Tundra ecosystems: a comparative analysis. Cambridge University Press, Cambridge, p. 81-114

Bryson, R. A. (1966). Air masses streamlines and the boreal forest. Geogr. Bull. 8: 228-269

Courtin, G. M., Kalliomaki, N. M., Hillis, T, Robitaille, R. L. (1991). The effect of abiotic factors on the overwintering success in the meadow vole, Microtus pennsylvanicus: winter redefined. Arc. Alp. Res. 23: 45-52

Elton, C., Nicholson, M. (1942). The ten-year cycle in numbers of lynx in Canada. J. anim. Ecol. 11: 215-244
Fayle, D. C. F., MacIver, D. C., Bentley, C. V. (1983). Computergraphing of annual ring widths during measurement. For. Chron. 59: 291-293

Fayle, D. C. F., Bentley, C. V., Scott, P. A. (1992). How did treeline white spruce respond to conditions around 1816 ? In: Harington, C. R. (ed.) The year without a summer? World climate in 1816. Canadian Museum of Nature, Ottawa, p. 281-290

Fox, J. F. (1978). Forest fires and the snowshoe hare - Canada lynx cycle. Oecologia 31.349-374

Fritts, H. C. (1976). Tree rings and climate. Academic Press, London

Fuller, W. A. (1977). Demography of a subarctic population of Clethrionmys gapperi: numbers and survival. Can. J. Zool. 55: $42-51$

Greenwood, J. J. D. (1987). Three-year cycles of lemmings and Arctic geese explained. Nature 328: 577

Guiot, J. (1985). Reconstruction of seasonal temperatures and sea-level pressures in the Hudson Bay area back to 1700 . Clim. Bull. 19: 11-59

Halpin, M. A., Bissonette, J. A. (1988). Influence of snow depth on prey availability and habitat use by red fox. Can. J. Zool. 66: 587-592

Hansson, L., Henttonen, H. (1985). Gradients in density variations of small rodents: the importance of latitude and snow cover. Oecologia 67: 394-402

Henttonen, H., Hansson, L., Saitoh, T (1992). Rodent dynamics and community structure: Clethrionomys rufocanus in northern Fennoscandia and Hokkaido. Annls. zool. fenn. 29: 1-6

Jacoby, G. C., D'Arrigo, R. (1992). Spatial patterns of treegrowth anomalies from the North American Boreal treeline in the early 1800s, including the year 1816. In: Harington, C. R. (ed.) The year without a summer? World climate in 1816. Canadian Museum of Nature, Ottawa, p. 255-265

Keith, L. B. (1963). Wildlife's ten year cycle. University of Wisconsin Press, Madison

Korpimaki, E., Norrdahl, K. (1989). Avian predation on mustelids in Europe 1: occurrence and effects on body size variation and life traits. Oikos. 55: 205-215

Krebs, C. J. (1988). The experimental approach to rodent population dynamics. Oikos 52: 143-149

Krebs, C. J., Meyers, J. (1974). Population cycles in small mammals. Adv. ecol. Res 8: 267-399

Lamb, H. H. (1982). Climate history and the modern world. Methuen, London

Lavoie, C., Payette, S. (1992). Black spruce growth forms as a record of a changing winter environment at treeline, Quebec, Canada. Arc. Alp. Res. 24: 40-49

Marchand, P. J. (1991). Life in the cold. University Press of New England, Hanover

Meslow, E. C.. Keith, L. B. (1971). A correlation analysis of weather versus snowshoe hare population parameters. J. Wildl. Mgmt 35: 1-15

Monserud, R. A. (1986). Time-series analyses of tree-ring chronologies. For. Sci. 32: 349-372

Newman, P. C. (1985). The company of adventurers. Penguin, New York

Pimm, S. L. (1991). The balance of nature? Ecological issues in the conservation of species and communities. University of Chicago Press, Chicago

Pruitt, W. O. (1978). Boreal ecology. Edward Arnold, London

Quinn, N. W. S., Thompson, J. E. (1987). Dynamics of an exploited Canada Lynx population in Ontario. J. Wildl. Mgmt 51: 297-305 
Schaffer, W. M. (1984). Stretching and folding in lynx fur returns: evidence for a strange attractor in nature? A.m. Nat. 124: 798-820

Scott, P. A. (1992). Annual development of climatic summer in northern North America: accurate prediction of summer heat availability. Clim. Res. 2: 91-99

Scott, P. A. (1993). Relationship between the onset of winter and collared lemming abundance at Churchill, Manitoba, Canada: 1932-1990. Arctic 46: in press

Scott, P. A., Bentley, C. V., Fayle, D. C. F., Hansell, R. I. C. (1987). Crown forms and shoot elongation of white spruce at the treeline, Churchill, Manitoba, Canada. Arc. Alp. Res. 19: 175-186

Scott, P. A., Fayle, D. C. F., Bentley, C. V., Hansell, R. I. C (1988). Large scale changes in atmospheric circulation interpreted from patterns of tree growth at Churchill, Manitoba, Canada. Arc. Alp. Res. 20: 199-211

Scott, P. A., Hansell, R. I. C., Erickson, W. R. (1993). Influences

Editor: V. Meentemeyer of wind and snow on treeline environments at Churchill, Manitoba, Canada. Arctic 46: in press

Shelford, V. E. (1943). The abundance of the collared lemming (Dicrostonyx groenlandicus (Tr.) var. Richardsonii Mer.) in the Churchill area, 1929 to 1940. Ecology 24: $472-484$

Sokal, R. R., Rohlf, F. J. (1981). Biometry 2nd ed. W. H. Freeman and Co., New York

Steen, H., Yoccoz, N. G., Ims, R. A. (1990). Predators and small rodent cycles: an analysis of a 79-year time series of small rodent population fluctuations. Oikos 59: 115-120

Suffling, R., Fritz R. (1992). The ecology of a famine: northwestern Ontario in 1815-17. In: Harington, C. R. (ed.) The year without a summer? World climate in 1816. Canadian Museum of Nature, Ottawa, p. 203-217

Wolfe, J. O. (1980). The role of habitat patchiness in the population dynamics of snowshoe hares. Ecol. Monogr. 50: $111-130$

Manuscript first received: December 8,1992

Revised version accepted: March 1, 1993 